\title{
LA CAPILLA MUSICAL DE LA COLEGIATA DE TALAVERA DE LA REINA EN LA PRIMERA MITAD DEL SIGLO XIX*
}

\section{THE MUSIC CHAPEL AT THE COLLEGIATE CHURCH IN TALAVERA DE LA REINA DURING THE $19^{T H}$ CENTURY}

Paulino Capdepón Verdú

Centro de Investigación y Documentación Musical-Unidad Asociada al CSIC

Universidad de Castilla-La Mancha

paulino.capdepon@uclm.es

ORCID iD: https://orcid.org/0000-0001-6509-3496

\begin{abstract}
Resumen
Tras la etapa de esplendor que vivió la capilla musical de la Colegiata de Santa María la Mayor de Talavera de la Reina durante el siglo XVIII, asistimos por el contrario a una fase de decadencia, que se enmarca en la crisis que experimenta la música religiosa española durante el siglo XIX. Los efectos de la Guerra de la Independencia, las sucesivas desamortizaciones y la aplicación del Concordato (1851) significaron una disminución del papel de las capillas musicales eclesiásticas en la España de aquella época e incluso algunas de ellas acabaron siendo suprimidas, como es el caso de la capilla talaverana.
\end{abstract}

\section{Palabras Clave}

Siglo XIX. Talavera de la Reina. Colegiata. Santa María la Mayor. Capilla de música. Decadencia. Maestro de capilla-organista.

\section{INTRODUCCIÓN}

Las sucesivas desamortizaciones propiciadas por distintos gobiernos de corte liberal, que afectaron negativamente la vida musical de las capillas musicales en la España de la primera mitad del siglo XIX, así como la firma del Concordato entre la Santa Sede y el gobierno de Isabel II supusieron ahondar la crisis de la música religiosa española, cuyos primeros síntomas se venían gestando ya desde finales

\footnotetext{
* Este artículo se enmarca en los resultados del proyecto de I+D "Patrimonio Musical de Castilla-La Mancha: análisis crítico, recepción y edición”. Ref.: HAR2013-47243-P.
}

\begin{abstract}
After the splendor of the music chapel at Santa Maria la Mayor Collegiate Church in Talavera de la Reina during the $18^{\text {th }}$ century, it can be perceived a phase of decadence, which is part of the crisis experienced by Spanish sacred music during $19^{\text {th }}$ century. The Independence War, the successive confiscations and the application of the Concordato (1851) resulted in the diminution of the role of ecclesiastical music chapels in $19^{\text {th }}$ century Spain: even some of them were deleted, as it is the case of the Talavera music chapel.
\end{abstract}

\section{Key Words \\ 19th century. Talavera de la Reina. Collegiate Church. Music Chapel. Decadence. Chapel Master-Organist.}

del siglo anterior. En el presente artículo tendremos la oportunidad de observar un claro ejemplo de todo ello en el caso concreto de la Colegiata de Santa María la Mayor de Talavera de la Reina ${ }^{1}$, institución fundada en 1218 a instancias

1 Los estudios sobre la Colegiata de Santa María la Mayor de Talavera de la Reina se han referido fundamentalmente a aspectos artísticos, destacando las aportaciones de LÓPEZ DE AYALA-ÁLVAREZ (1959); NICOLAU CASTRO (1971); (1982). BALLESTEROS GALLARDO (1981); o bien históricos: BALLESTEROS GALLARDO (2003); MENDOZA EGUARÁS, TORROJA MENÉNDEZ (1969). La más reciente contribución de carácter colectivo al conocimiento de la historia y arte en la Colegiata talaverana puede consultarse en 
del Arzobispo de Toledo, Rodrigo Jiménez de Rada, con el fin de solicitar auxilios para hacer frente a la guerra contra los almohades: los vecinos de Talavera presentaron al Rey y al citado Arzobispo la solicitud de que la parroquia de Santa María se reconvirtiese en Colegial a causa del aumento poblacional, petición que fue aceptada por Jiménez de Rada ${ }^{2}$; efectivamente, en julio del mismo año de 1211, el citado Arzobispo expidió una Constitución, autorizada y confirmada por los canónigos y dignidades de su Cabildo, en la que se mencionan las circunstancias de la erección de la Colegial de Talavera. Según dicho prelado, debido a la devoción de esta iglesia y a los ruegos de sus clérigos, la antigua parroquia se constituyó en conventual para que en ella siempre estuvieran presentes canónigos dedicados al culto, fundándose varias dignidades y fijando sus deberes para con la Mitra de Toledo, que los canónigos de Talavera por su parte reconocieron. De esta forma fue creada la nueva Colegiata de la Asunción de Nuestra Señora ${ }^{3}$.

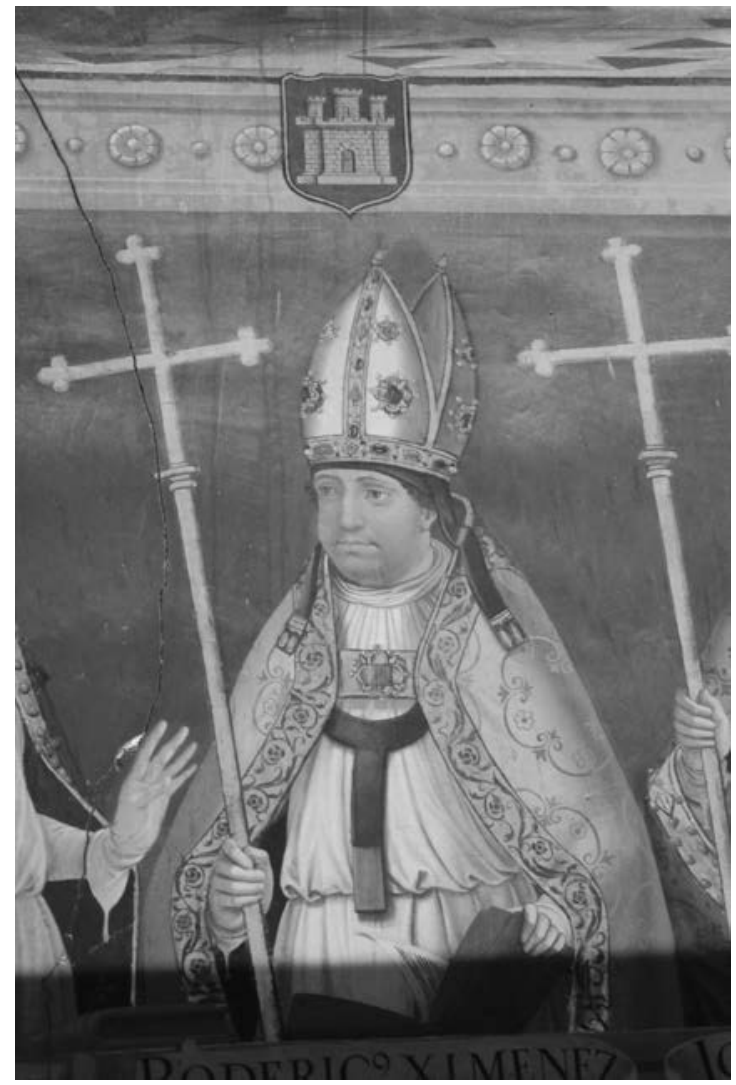

Fig. 1. Juan de Borgoña: Retrato del Arzobispo Rodrigo Jiménez de Rada (ca. 1510)

BALLESTEROS GALLARDO (2013). Por su parte, la música sólo ha comenzado a ser tratada en los últimos años gracias a CAPDEPÓN (2012); (2013); (2016): ni siquiera en el Diccionario de la Música Española e Hispanoamericana o en LEZA (2014) se hacía referencia alguna a Talavera de la Reina, a la existencia de una capilla de musical o a los maestros, organistas y músicos que ejercieron su labor creativa en dicha capilla de la Colegiata salvo el caso de GARBAYO (2000), (2002); MESSA POULLET (2000) y BARRIOS (1991), si bien no hacían alusión a la estancia de distintos maestros y organistas en Talavera sino a un destino anterior o posterior en otros centros eclesiásticos. 2 FERNÁNDEZ Y SÁNCHEZ (1893): 183.
3 Según LÓPEZ DE AYALA (1959): 306-307, se conserva una copia de dicha Constitución bajo el título de Constitutio super ecclesia Sancta Marie de Talavera que sit conventualis procreandis ibidem canonicis et personis en el Archivo Histórico Nacional: Liber privilegiorum de la Iglesia de Toledo. Asimismo, y siguiendo a FERNÁNDEZ Y SÁNCHEZ (1893): 183-184, existe otra copia en el archivo de la Colegiata, extendida en hoja de pergamino y escrita en latín del siglo XIII (Archivo de la Colegiata de Talavera de la Reina -en adelante ACTR-, Carpeta 255/1), de la cual obtuvo una copia testimoniada en castellano el 14 de enero de 1831 el entonces escribano de Talavera, Clemente Pabón, a instancia del Deán, Manuel González, bajo el título de Erección de la Insigne y Santa Iglesia Colegial de Talavera. Año MCCXI. Mensis Julio. $=n^{\circ}$ 1. Esta es la Bula de erección de esta santa Iglesia Colegial de Talavera. Año de 1211. 
Cuando se firma el Documento fundacional de la Colegiata de Talavera en julio de $1211^{4}$ todavía no se había olvidado la terrible derrota de las tropas del rey Alfonso VIII de Castilla por las tropas almohades comandadas por el califa Yúsuf II en Alarcos, acaecida 16 años antes ${ }^{5}$. Por tal razón y en opinión de Gonzálvez,

El acto, pues, de la elevación de la iglesia de Santa María de Talavera a la categoría de colegiata está enmarcado y necesariamente relacionado con todo lo que se estaba gestando en Castilla en aquel año decisivo. Del lado cristiano, todos estaban convencidos de lo que se jugaba en aquella ocasión, nada menos que la supervivencia del reino. A la población se le exigió el máximo esfuerzo. Nadie estaba seguro de que no se iba a repetir de nuevo la derrota de Alarcos ${ }^{6}$.

Lo cierto es que la elevación de Santa María a la categoría de colegiata representa la concesión de un privilegio que en el siglo XIII colocó a esta iglesia talaverana por encima de todas las restantes iglesias de la diócesis y en una posición sólo inferior a la Catedral de Toledo ${ }^{7}$. Pese a ello, con anterioridad al Documento fundacional de 1211 Santa María la Mayor ya gozaba de cierta primacía sobre el resto de centros eclesiásticos de Talavera, prueba de lo cual es el documento más antiguo conservado en su archivo, tal como señala Jaime Olmedo: se trata de un concierto de mayo de 1204 por el que los clérigos de las parroquias de Talavera (San Pedro, San Salvador, Santa Leocadia y Santa Eugenia, San Miguel, Santiago, San Clemente, San Esteban y San Martín) estaban obligados a asistir a la procesión y misa de la iglesia de santa María de Talavera en la vigilia de la Asunción y en los días de la Anunciación y Purificación de la Virgen ${ }^{8}$.

A causa de la situación ruinosa en que se encontraba la colegiata, se procedió a su reedificación con la significativa contribución de donativos a cargo de caballeros y pecheros de la villa así como con limosnas de los vecinos. Gracias a las disposiciones adoptadas por el Arzobispo Jiménez de Rada, el Cabildo se formó con doce canónigos y cuatro dig-

4 Dicho documento ha sido investigado por GONZÁLVEZ (2013): 33-81.

5 Consúltese al respecto IZQUIERDO, RUIZ (1996).

6 GONZÁLVEZ (2013): 40

7 Ibidem: 60.

8 OLMEDO (2013): 19. Asimismo, una sentencia de 27 de mayo de 1295 obligaba a los clérigos talaveranos a que "vayan a la Colegiata con sus cruces y sobrepellices el domingo de ramos, los tres días de las letanías que preceden a la Ascensión el sábado de Resurrección y la vigilia de la Asunción". Véase MENDOZA, TORROJA (1969): 166; citado en OLMEDO (2013): 19. nidades (Deán, Sodeán, Chantre y Tesorero), además de las ya existentes de Arcediano de Talavera, con silla por derecho propio junto al prelado en el Cabildo toledano, y de Arcipreste de Calera. Posteriormente se suprimió la dignidad de Sodeán, siendo sustituida por la de Arcipreste. Al respecto afirma lo siguiente Sánchez y Fernández:

El arcedianato de Talavera, además del arciprestazgo de Calera, que comprendía treinta y seis iglesias parroquiales, extendía su autoridad a otros tres arciprestazgos: el de Escalona, con veintiocho parroquias; el de Maqueda, con dieciocho; y el de Santa Olalla, con veintiocho parroquiales, perteneciendo también a Talavera la vicaría de Alcocer de Tajo, con trece parroquias?.

Desde 1212 los objetivos del Cabildo se centraron en aumentar su patrimonio, rentas y sus propiedades gracias a donaciones reales, particulares, compras y permutas, el control de las propiedades de las Órdenes Militares y el apoyo a los reyes en sus conquistas con una doble finalidad: propagar el cristianismo y la fe y conseguir nuevos dominios en las tierras conquistadas, haciendo posible que los señoríos de realengo pasaran a convertirse en señoríos eclesiásticos ${ }^{10}$. Durante el mandato del Arzobispo talaverano Pedro Tenorio (1328-1399) ${ }^{11}$, las obras del templo cobraron un gran impulso durante aquella época, restaurándose el templo primitivo merced a las limosnas donadas por los vecinos, gracias a lo cual se acrecentó la importancia de la Colegiata en la vida religiosa de Talavera. En 1375, a instancias del citado Arzobispo, se derribó parte del antiguo templo de Santa María, erigido sobre la mezquita mayor de la ciudad y se comenzó a construir en el mismo solar una nueva Colegial que sólo se completará en la década de 1520-1530 con la construcción de parte de la torre y el claustro ${ }^{12}$.

El siglo XV señala una época de verdadera eclosión para la Colegiata, que vio ampliado su edificio merced a nuevas e importantes donaciones y al favor que le prestaron los prelados de Toledo: así por ejemplo, un Arcediano de la Colegial cedió al Cabildo las dehesas de Pelabanegas o Pedro Venegas y del Quejigoso. Por su parte, el Arzobispo de Toledo, Alonso Carrillo, otorgó licencia al Cabildo en 1461 para empeñar toda la plata labrada del culto mientras que

9 FERNÁNDEZ Y SÁNCHEZ (1893): 184.

10 PORTELA HERNANDO (2013): 253.

11 Sobre la decisiva intervención del arzobispo Pedro Tenorio en relación al cisma de Occidente, véase ÁLVAREZ PALENZUELA (1982): 82. Para conocer el grado de influencia de este arzobispo en la España de su tiempo, consúltense asimismo SUÁREZ FERNÁNDEZ (1953) y LÓPEZ DE AYALA (1979).

12 PORTELA HERNANDO (2013): 253. 
el papa Sixto IV concedió en 1475 el lugar del Pedroso y sus anejos. Como resultado de todo ello, se fomentaron las obras, se cerraron las últimas bóvedas y se erigió en el centro de la iglesia el coro, con su doble sillería alta y baja, que en la actualidad no se ha conservado ${ }^{13}$.

La fisonomía de Talavera y su colegiata fue modificándose desde comienzos de la era moderna ${ }^{14}$ : así por ejemplo, en 1576 se afirma que "de cincuenta años a esta parte es más sana a causa de los edificios que se han hecho, y vivir en altos y no en bajos como solían, y por estar las calles bien aderezadas y empedradas", lo cual reducía los efectos de la humedad que emanaba de un Tajo caudaloso "y de recia corriente" que "bate en los muros" de la ciudad" ${ }^{15}$. Dicha transformación puede vislumbrarse en la vista de Talavera que nos ha legado Anton van Wyngaerde en el marco del encargo de Felipe II para que este paisajista holandés dibujara pueblos y ciudades españoles a partir de 1561 .

\section{TALAVERA DE LA REINA EN LA PRIMERA MITAD DEL SIGLO XIX}

Talavera de la Reina inició el nuevo siglo con una serie de problemas económicos y sociales que ofrecen su mejor manifestación en la grave crisis de 1804 debido a la mala cosecha. El Ayuntamiento se vio en la obligación de crear una Junta de Socorro y Beneficencia en aquel año, a imitación de otras poblaciones y la falta de pan obligará a importar grano de Toledo, Madrid y otros lugares ${ }^{16}$. Tales problemas de subsistencia se traducirán en secuelas de hambre, paro, carestía y conflictividad social, la cual se agudiza durante la Guerra de la Independencia ${ }^{17}$ y en los años sucesivos, llegando a convertirse en movimientos revolucionarios, como el que tendrá lugar en $1868^{18}$.

Con motivo de la mencionada Guerra de la Independencia, Talavera será ocupada por las tropas francesas el 11 de diciembre de 1808 hasta el verano de 1809 y tras una breve interrupción propiciada por la Batalla de Talavera, favorable a los intereses hispano-ingleses, continuará

13 LÓPEZ DE AYALA (1959): 307.

14 Véase al respecto PACHECO, VALVERDE (1994): 32-56.

15 Relaciones histórico-geográfico-estadísticas de los pueblos de España hechas por iniciativa de Felipe II. Reino de Toledo, Primera parte, ed. de Carmelo Viñas y Ramón Paz, CSIC, Madrid 1951, págs. 447s. Citado en OLMEDO (2013): 24.

16 Véase al respecto GARCÍA RUIPÉREZ (1994): 212-222. Un estudio más amplio sobre esta cuestión puede consultarse en su tesis doctoral (2002).

17 La cuestión de la beneficencia en Talavera durante la Guerra de la Independencia ha sido estudiada por SÁNCHEZ-GARNICA (2003): 60-72.

18 Cf. PACHECO (1994): 225-239. desde agosto de 1809 hasta 1812 con unas consecuencias ciertamente desastrosas para la villa toledana. Las noticias del final de la guerra se reflejaron en las actas municipales a lo largo de 1813: en el caso de la toma de Pamplona, por ejemplo, se dispuso la celebración de una misa y el repique general de campanas así como iluminaciones en los balcones y ventanas de la ciudad ${ }^{19}$.

En Talavera se experimentará el drama que por entonces vivían los liberales bajo la primera etapa del gobierno absolutista de Fernando VII, llegando incluso a la persecución personal y a la quema pública tanto de los ejemplares existentes de la Constitución de 1812 como de ejemplares de publicaciones de carácter liberal. Ello irá acompañado por la adopción de medidas populistas como la rebaja del precio del pan con el fin de ganar la población a la causa del monarca.

Por lo que concierne a las guerras carlistas, Talavera permaneció fiel a la causa isabelina. Precisamente fue en esta villa donde tuvo lugar uno de los primeros estallidos carlistas a cargo de un reducido grupo de insurrectos, cuya intentona fue rápidamente abortada y sus responsables, ejecutados. Efectivamente, se puede adjudicar a dicho pronunciamiento la primacía temporal durante la Primera Guerra Carlista, que asoló España entre 1833 y 1839, pronunciamiento que tuvo lugar el 2 de octubre de 1833 y fue protagonizado por Manuel María González, comandante del Batallón talaverano de los Voluntarios Reales. Este suceso ha sido estudiado por Félix Rubio, quien explica el levantamiento en base a las reformas que el gobierno planeaba en el sentido de ir sustituyendo progresivamente el cuerpo de Voluntarios Reales por las Milicias urbanas, más proclives a la causa isabelina y liberal:

Sin embargo, ante la nuevas realidades políticas del momento, los "Voluntarios" tendían a convertirse cada vez más en un estorbo y en una fuente constante de conflictos; y sobre todo por la independencia con que resolvían sus actuaciones y por las excesivas atribuciones que ellos a sí mismos se otorgaban, hasta el punto de originar problemas de jurisdicción con juzgados y ayuntamientos, tal y como ocurre en Talavera" ${ }^{20}$.

El geógrafo e historiador Sebastián Miñano nos presenta en 1827 una descripción de la ciudad nada favorable:

19 Archivo Municipal de Talavera (AMT), Libro de acuerdos de 1813, 7 de noviembre de 1813, fol. 206r. Citado en PEÑALVER (2006-2007): 81 .

20 RUBIO (1987): 16; consúltese asimismo RUBIO (1988): 6367; PRIETO ARAÚJO (2009): 241-283. Sobre esta cuestión en particular y sobre el carlismo en general es esencial el trabajo de ARÓSTEGUI (1981): 69-139. 


\begin{abstract}
El caserío de la villa en general es malo; las casas antiguas que no están arruinadas son grandes, desabrigadas y destituidas de toda comodidad; las nuevas son pequeñas, mezquinas y ahogadas; las fachadas irregulares, y algunas de muy poca altura. Las calles son angostas, tortuosas y muy mal empedradas; no hay aceras, alumbrado ni ninguna policía. Las aguas inmundas se vierten a la calle o salen a ella por albañales formando en medio de cada una un arroyo de porquería pudiendo salir por cañerías cubiertas al río, que está mucho más bajo; las salidas al campo o los extremos de la población están llenos de muladares hediondos, perjudiciales a la salud, lo que reunido todo da al pueblo un aspecto feo, desagradable y triste. No sucede así con el campo, que es muy hermoso y muy alegre; por cualquiera parte que se salga se encuentra un buen paseo" 21 .
\end{abstract}

Otro factor que incide en la Talavera del siglo XIX es el proceso desamortizador: como núcleo que aglutina una extensa comarca, se vio afectada poderosamente por las desamortizaciones pues conservaba muchas tierras, la mayor parte de las cuales eran de propiedad eclesiástica: puede dar idea de la magnitud de suelo rústico de titularidad eclesiástica el hecho de que en Talavera se asentaban trece comunidades religiosas, a cuyas propiedades es necesario sumar las del clero secular, distribuido en siete parroquias así como numerosas instituciones como cofradías, ermitas y hospitales, todas ellas con bienes, fundaciones o memorias vinculadas. Independientemente de ello, había que tener en cuenta los bienes de Propios municipales, del Estado y bienes mostrencos, repartidos por la ciudad y su comarca, que, distribuidos en 39 fincas rústicas, sumaban más de 11000 fanegas de tierra, con un valor aproximado de casi tres millones de reales ${ }^{22}$.

El Padrón General del Estado, compilado en 1802 y 1816 con fines recaudatorios, posibilita comprobar el escaso número de vecinos nobles en Talavera, que apenas llega al 3\%, dado que parte de los apellidos nobiliarios han desaparecido de los registros y que buena parte de los más significados que todavía perduran, acaban residiendo en Madrid, si bien siguen conservando sus propiedades rústicas y urbanas en Talavera. Así pues, y al igual que ocurre en el resto de España, es perceptible una tendencia paulatina en la disminución del estamento nobiliario, que ha llegado al siglo XIX en un estado de decadencia cada vez mayor ante la desvalorización del ideal caballeresco y la negación de

21 MIÑANO (1827): 376

22 BLANCO (2006-2007): 111. Para mayor información sobre el alcance e impronta de la desamortización en Talavera consúltense asimismo FEIJOO GÓMEZ (1990). títulos dudosos, siendo sustituido por la burguesía emergente $^{23}$.

Los servicios existentes en la Talavera de 1827 eran los siguientes: Ayuntamiento, con un corregidor de primera clase y 12 regidores, Subdelegación de policía, Administrador de rentas reales, Contaduría, Aduana, Administración principal de Correos, Tribunal eclesiástico foráneo, Casa de Posta con 6 caballos, Puente y Portazgo de Alberche ${ }^{24}$. Por su parte, el Diccionario geográfico-estadístico-histórico de Pascual Madoz nos ofrece información precisa sobre los contribuyentes y servicios en 1849:

- Contribuyentes: 596, equivalentes al 38'2\% del total del vecindario.

- Servicios: cárcel, pósito, posadas, café, billares, comandancia de armas, teatro, escuela elemental completa gratuita, escuela primaria superior gratuita, tres escuelas de niños privadas, cuatro escuelas de niñas privadas y con maestras tituladas ${ }^{25}$.

- Total de riqueza imponible: 639.968 reales de vellón.

- Total de la contribución del Ayuntamiento: 491.538 reales vellón ${ }^{26}$.

El hecho más novedoso de esta etapa que nos ocupa viene dado por el surgimiento y asentamiento de una nueva oligarquía burguesa comercial e industrial y de unas clases medias que se fortalecerán conforme avance el siglo. En ocasiones se trata de poderosos terratenientes, lo cual confirmaría en opinión de José Luis Blanco

la tradicional conexión talaverana entre la gran propiedad agraria y el elemento ganadero, que siguen constituyendo las bases locales económicas y de poder: resulta paradigmático, por ejemplo, el caso de Antonio Julián de Belluga, reconocido agricultor y ganadero que en 1812 figura como Corregidor y en 1841 estaba al frente del consistorio talaverano ${ }^{27}$.

Por el contrario, la población pechera alcanza casi el $71 \%$. Cuando la ciudad está inserta en plena recuperación de la contienda contra los invasores franceses, se observa que en 1816 la nobleza ha incrementado levemente su proporción pero paralelamente, el número de pecheros es aún mayor: al igual que ocurría en todo el interior peninsular, siguen permaneciendo las malas condiciones socio-económicas que habíamos señalado en el siglo anterior para este

23 GONZÁLEZ MUÑOZ (1975): 374-375.

24 MIÑANO (1827): 375.

25 Sobre el sistema de enseñanza en Talavera durante el siglo XIX, cfr. MONTERRUBIO PÉREZ (1999).

26 MADOZ (1849): 565-574.

27 BLANCO (2006-2007): 96. 
sector de la población, que ve agravar su situación merced a las continuas carestías, epidemias y hambres. Por otra parte, la anterior liberalización del comercio interior de granos en 1765 así como el régimen de mercado libre de 1834 repercuten negativamente sobre el campesinado, que sufrirá tanto la escasez como las subidas coyunturales de precios causadas por las malas cosechas, el mal estado de las comunicaciones y el insolidario comportamiento de los especuladores. En cualquier caso, especialmente penosa era la situación de los jornaleros, a muchos de los cuales podía verse deambular por la Plaza del Reloj ofreciendo su trabajo ${ }^{28}$.

Por otra parte, el siglo XIX presencia en Talavera una gran disminución de clérigos y número de conventos así como la venta de muchos de sus bienes a causa de las diferentes desamortizaciones que tuvieron lugar durante la primera mitad de aquel siglo. En años como 1802 y 1816 sólo están censados 36 y 12 clérigos, respectivamente ${ }^{29}$; por su parte, Miñano cita en 1827 la existencia de

una iglesia colegial, 7 parroquias que tienen para su servicio 8 eclesiásticos y 2 beneficiados simples, pues aunque hay hasta 16 fundaciones más de beneficios simples, los poseen manos muertas o los disfrutan otros prebendados; hay también un monasterio de Jerónimos, cuya renta fija no baja de 400000 reales anuales; 7 conventos de frailes, 5 de monjas, todos de pocas rentas; un santuario fuera del pueblo dedicado a Nuestra Señora del Prado $^{30}$.

El hecho de que Santa María la Mayor perdiera su condición de colegial, a lo que se añadió los reajustes y el cierre de otros centros eclesiásticos, se tradujo asimismo en una reducción radical de la población clerical que vivía en la ciudad toledana ${ }^{31}$. Asimismo es digno de resaltar que la anterior abundancia y riqueza de las instituciones eclesiásticas durante el siglo XVIII, como tendremos la ocasión de comprobar a continuación en el caso concreto de la Colegiata de Santa María la Mayor, disminuirá drásticamente, lo cual se percibe fundamentalmente en los monasterios de frailes talaveranos, que irán desapareciendo casi en su totalidad, conservándose sólo los conventos de monjas, que sumaban 60 profesas en 1882 .

Apenas poseemos datos para conocer la estructura profesional en Talavera durante la primera mitad del siglo XIX, proporcionando documentación sólo algunas parroquias. Así

28 Ibidem: 105-106.

29 HERNÁNDEZ LANCHAS (1991): 24.

30 MIÑANO (1827): 375-376.

31 Se llegó al número de diez clérigos en 1892. Ibidem: 391. por ejemplo, la parroquia de San Salvador en 1814 arroja un predominio de los obreros sin especializar en un porcentaje del $31^{\prime} 6 \%$ del vecindario, seguido del sector de los tejidos con un $4 ' 1 \%$ y el cuero y calzado, con un 3'6\%, división que se mantuvo hasta mediados de siglo aproximadamente, cuando el declive y posteriormente la supresión de la Fábrica de Sedas en $1851^{32}$ supondrá un golpe definitivo a la anterior importancia de los tejidos y confecciones, lo cual provocó un reajuste profesional en toda la ciudad, pero especialmente en los barrios aledaños a dicha fábrica: de hecho, y tal como demuestra fehacientemente la doctora González Muñoz, en el censo de 1860 ya no se alude a la industria textil a la hora de recoger la estructura profesional, artes y oficios ${ }^{33}$.

La recuperación económica se vio lastrada no sólo por el escaso crecimiento poblacional, sino también por fenómenos como la aparición del cólera ${ }^{34}$, a lo que se unió la supresión en 1851 de la Real Fábrica de Sedas que en sus últimos años de existencia era ya una sombra de lo que llegó a representar para la economía de Talavera, tal como apuntábamos anteriormente. La ruina económica afectará también a la industria de la cerámica a causa fundamentalmente de la Guerra de la Independencia, la cual perjudicó muy negativamente a la industria de la alfarería pues se destruyó buena parte de la Cañada de Alfares y el Barrio de San Ginés: dicha industria experimenta en el siglo XIX su peor momento: de los cinco alfares apenas resistirán uno o dos, siendo necesario esperar al siglo XX para que resurja ${ }^{35}$.

Por lo que se refiere a una de las bases esenciales de la economía talaverana, la agricultura, en el siglo XVIII se había propuesto una batería de medidas (fomento del regadío, aprovechamiento de todas las tierras cultivables, solución del problema de los arrendamientos y extensión de los cultivos industriales) que en el XIX intentan aplicarse gracias a las disposiciones legislativas del liberalismo económico ${ }^{36}$. En líneas generales, puede afirmarse que la agricultura del Ochocientos en Talavera ofrece un panorama semejante al que pueda presentar otras zonas como la cuenca mediterránea: predominio de cereales y leguminosas, productos bási-

32 A pesar de su valor arquitectónico e histórico, el edificio fue derruido en 1973 con la aprobación del propio Comisario General de Patrimonio Artístico Nacional de la época, quien lo consideró "sin gran interés, excepto una portada y un patio". Citado en GONZÁLEZ MUNOZ (2010-2011): 174.

33 GONZÁLEZ MUÑOZ (1975): 392-393.

34 Sobre esta epidemia y sus consecuencias en Talavera véase CARRASCO (2001-2002): 47-68. Por lo que se refiere a la provincia de Toledo, cfr. FERNÁNDEZ GONZÁLEZ (1983): 151-175.

35 GONZÁLEZ MUÑOZ (1975): 369.

36 BLANCO (2006-2007): 96. Son fundamentales en este sentido los estudios de YOSHIUKI KONDO (1990) y PINILLA NAVARRO (2004): 137-162. 
cos en la alimentación humana y animal, y en segundo lugar, cultivo de la vid, olivo y sus derivados, a lo que es necesario añadir en el caso concreto talaverano, la producción hortofrutícola de su vega.

Una vez superada la contienda bélica, la labor desamortizadora afectó negativamente la ganadería talaverana al restablecer en 1836 la Ley de Acotamientos de 1813 y la correspondiente extensión del cereal en detrimento de la cabaña ovina, predominante en Talavera junto al ganado de cerda. La evolución histórica de este ámbito productivo oscila entre la crisis y el afianzamiento: al igual que la agricultura, dicha evolución estará marcada por el atraso técnico y por la constante pugna entre agricultores y ganaderos, manifestada en las actuaciones del Honrado Concejo y la Mancomunidad de Pastos de la Antigua Tierra de Talavera, la cual se enfrentará a los defensores del principio liberal que daba derecho a acotar las propiedades, tal como ha estudiado Leandro Higueruela ${ }^{37}$.

La base de la industria talaverana durante la primera mitad del siglo XIX sigue estando basada en la Real Fábrica de Sedas y en la alfarería. En referencia a la citada Fábrica, había experimentado un crecimiento espectacular, pasando de 4000 hebras en un principio a 30000 a finales del siglo XVIII: sin embargo desde esta fecha en adelante, se inicia una decadencia relativa a causa de la competencia de los gremios madrileños. En 1797 son unos 1285 los trabajadores de la fábrica, cifra inferior a las registradas con anterioridad: produce sobre todo telas ricas, terciopelos y flequillos de oro y plata, así como seda que era vendida en Madrid, concretamente en el almacén de los cinco Gremios. La industria talaverana se completaba con pañuelos, cintería, listonería, medias y cortes de chupas, siendo los beneficios totales de dicha actividad en torno a los sesenta millones de reales ${ }^{38}$. Por lo que se refiere a otro de los puntales de la industria de Talavera de la Reina, la alfarería, hacia 1791 se mantenían cinco alfares de fino pero uno de ellos no trabaja desde seis años antes por haber acumulado excesivo material sin salida comercial. Finalizando el siglo el censo de 1797 sólo incluye a 17 alfareros y 10 barreros, representando un 2,1\% de las restantes profesiones. La Guerra de la Independencia, durante la cual es destruida buena parte de la Cañada de Alfares y el Barrio de San Ginés, significará una herida de muerte, que conoce a lo largo del siglo XIX su peor momento y de los cinco alfares apenas resistirán dos. Miñano la describe de la siguiente manera en 1827 y además nos ofrece interesante información sobre otros ámbitos de la industria talaverana:

37 GONZÁLEZ MUÑOZ (1975): 365.

38 MIÑANO (1827): 378.
La loza que aquí se fabrica es la que comúnmente se usa en Extremadura y las dos Castillas; es ordinaria, pesada, quebradiza, y resiste muy poco el calor; con todos estos defectos que tiene, es de creer que permanecerá siempre en el mismo estado sin adelantar en su perfección porque así deja ganancia muy considerable respecto al capital que exige un alfar; se gradúa en 180.000 reales el importe de lo que se cuece cada año; con todo, aseguran que en tiempos anteriores se fabricaba doble que ahora. A más de loza blanca se hacen gran cantidad de pucheros, cazuelas, ollas, cántaros, etc. que se despachan a buen precio para el surtido de los pueblos inmediatos por su buena calidad. También se labran velas de cera, chocolates y dulces. Se curten cordobanes y se hace jabón en cantidad suficiente para el consumo del pueblo ${ }^{39}$.

Por lo que se refiere al comercio, el propio Miñano define el comercio talaverano de 1827 como "pasivo y de poca consideración" ${ }^{40}$ : hubiera sido trascendental para la mejora del comercio de Talavera la canalización del Tajo, un proyecto que venía gestándose desde el reinado de Felipe II y resucitado en 1829 para olvidarse definitivamente ante la merma de caudal del río, sangrado por regadíos y abastecimiento de pueblos.

\section{LA COLEGIATA DE SANTA MARÍA LA MAYOR EN LA PRIMERA MITAD DEL SIGLO XIX}

Los comienzos del siglo XIX vienen marcados por el inicio de la decadencia de la Colegiata de Talavera. Ya en 1804 se manifiesta el estado de "indigencia" en que se encuentran los racioneros al no haber sido posible el reparto de granos, parte sustancial de su ración, por lo que solicitan que se les asista: ante ello, el Cabildo simplemente se da por enterado, sin que se adopten medidas urgentes:

Memorial de los racioneros. Luego se leyó un memorial de los racioneros de esta santa Iglesia, en que solicitan que mediante su corta dotación, lo escaso de este año, no haber recibido porción alguna de granos de los que tienen ganados y ser notoria su indigencia, se les asista con un socorro suficiente ínterin que se reparten los granos de heredades. En cuya vista, expresó el Cabildo quedar enterado ${ }^{41}$.

39 MIÑANO (1827): 378.

40 Ibidem.

41 ACTR, Actas Capitulares, Acta de 7-9-1804, vol. 22, fol. 
La tensa situación que vive España alcanza un momento álgido en 1804 con motivo de la expansión de la epidemia de la fiebre amarilla en diferentes zonas de España. Tal como afirma Ángel González de Pablo, "tres fueron los grandes problemas a los que hubo de enfrentarse la política socio-sanitaria de los gobiernos ilustrados: la enfermedad, el hambre y el abandono infantil... En cuanto al primero de ellos, la peste, que había sido el gran azote durante el siglo XVII, fue reemplazada en su incidencia social por la malaria, el tifus y, ya iniciado el XIX, por la fiebre amarilla" ${ }^{2}$. Ese mismo año, y al verse afectada la propia Talavera por la mencionada epidemia, se crea la Junta de Sanidad en la villa desde el 30 de septiembre de 1804, a la que pertenecen las principales autoridades políticas, militares, económicas, religiosas y sanitarias: dos regidores del Ayuntamiento, el Deán de la Colegiata, el Vicario, el comandante militar de la villa, el director de las Reales Fabricas y los médicos más renombrados ${ }^{43}$. La virulencia de la epidemia de fiebre amarilla a partir de septiembre de 1804 motiva que se ordenen rogativas en las principales instituciones eclesiásticas del reino, tal como se puede apreciar en un acta capitular de la Colegiata $^{44}$.

Al igual que ocurrió en toda España, la Guerra de la Independencia tuvo consecuencias catastróficas para Talavera y sus efectos se dejaron sentir en la Colegial. A principios de agosto de 1809 entraron en la población el Mariscal Duque de Belluno y otros generales franceses con sus tropas: Talavera sufrió durante siete días las consecuencias de un saqueo generalizado y la soldadesca penetró en la Colegial, que fue diezmada ${ }^{45}$, mientras que el expolio de oro y plata por parte del gobierno intruso no pudo evitarse. Por otra parte, se arrasaron las dehesas y labranzas del Chaparral y Valdelacruz, además de rentas y bienes del Hospital de la Misericordia ${ }^{46}$.

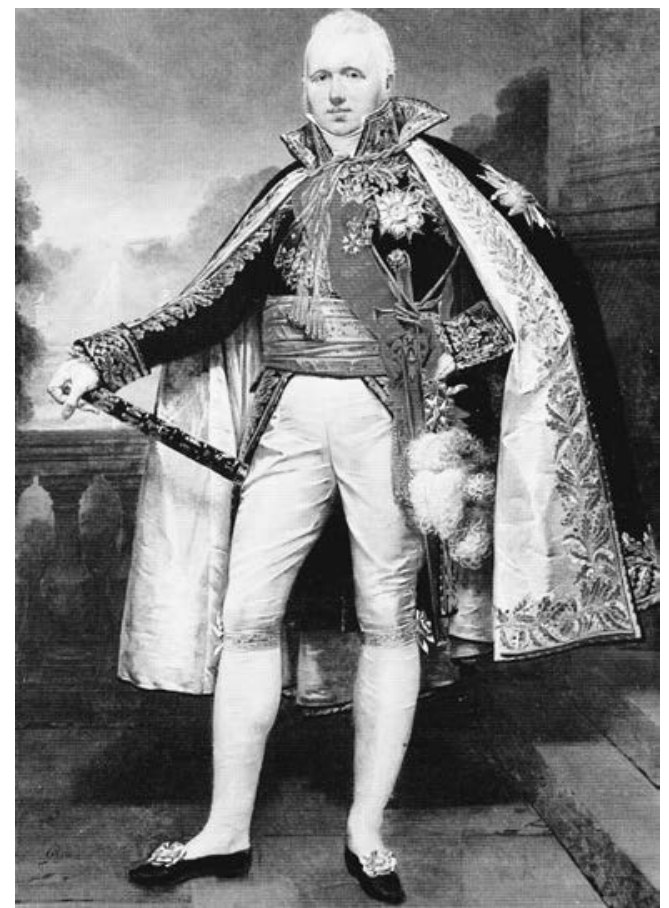

Fig. 2. Antoine-Jean Gros: Retrato de Claude-Victor Perrin, duque de Belluno, mariscal de Francia (1812)

43 AMT, Secretaría. Sanidad. Junta de Sanidad: correspondencia, actas, contabilidad, expedientes. 1800-1808. Sig. 212.

44 ACTR, Actas Capitulares, Acta de 16-9-1804, vol. 22, fol. 176v. Sobre la fiebre amarilla o vomito negro, $c f r$. FIGUERA.

45 Consúltese la descripción de FERNÁNDEZ Y SÁNCHEZ (1893): 86ss. Para ampliar información sobre la repercusión de la Guerra de la Independencia en el ámbito eclesiástico, cfr. HIGUERUELA (1983).

46 GARCÍA MARTÍN (2013): 396. Consúltense asimismo PÉREZ GRANDE (1985) y GARCÍA MARTÍN (2004). 
Una vez finalizada la contienda, el Cabildo talaverano, dado el estado deplorable en que había quedado la organización administrativa de la Colegiata, se ve en la obligación de informar al Arzobispo en 1815 sobre la situación en relación a la dotación de prebendas para determinar cuáles son realmente necesarias y cuáles pueden suprimirse:

Número de prebendas. Se leyó una orden de Su Eminencia, fecha catorce de marzo próximo, en que se inserta la de la Real Cámara para que el Cabildo informe acerca del número de prebendas que existen en esta Iglesia y deben existir: las que se hallen vacantes; las que se residen o no; las que se consideren necesarias para el culto divino; y de las que podría suspenderse la provisión con otros particulares. Y visto por el Cabildo, que la contaduría informe haciéndose este presente al Cabildo ${ }^{47}$.

En esa misma época, la reconstrucción del país tras la Guerra de la Independencia obliga a la Colegiata a una contribución económica para el sostenimiento de las fuerzas armadas:

Leyóse carta del eminentísimo señor Cardenal Arzobispo de Toledo, de seis de este mes, en que hace referencia a la orden de Su Majestad, en que se invita a todos los eclesiásticos a contribuir con lo que puedan para mantener el ejército que a consecuencia de las ocurrencias públicas ha de reunirse en las fronteras del reino, confiando en el amor y lealtad al soberano y celo por la seguridad de la patria. Y enterado el Cabildo, acordó se vea lo que en igual o semejante caso se representó a Su Eminencia y con sujeción a lo mismo se conteste ${ }^{48}$.

A pesar de los problemas de subsistencia y del estado de Talavera y del país en general, es perceptible el deseo de recuperar las festividades y tradiciones religiosas de la Colegiata de Talavera de la Reina que durante la ocupación francesa habían prácticamente desaparecido, como es el caso de las funciones eclesiásticas y de la celebración de procesiones:

Sobre antiguas funciones de iglesia. Se presentaron los señores regidores don José Jiménez del Aliso y don Bartolomé Castillejo y Marqués, comisarios del ilustre Ayuntamiento y propusieron que éste había acordado restablecer y continuar todas las antiguas funciones

47 ACTR, Actas Capitulares, Acta de 7-4-1815, vol. 23, fol. $113 \mathrm{v}-114 \mathrm{r}$.

48 ACTR, Actas Capitulares, Acta de 21-4-1815, vol. 23, fol. de Iglesia, como se venían haciendo hasta el año mil ochocientos ocho, confiando en que este ilustre Cabildo contribuirá por su parte a tan piadoso restablecimiento. Y enterado, lo estimó todo según la propuesta, con lo cual se despidieron los señores regidores ${ }^{49}$.

Procesiones de tabla. Se trató del restablecimiento de las procesiones de tabla de esta iglesia que a causa de las lastimosas ocurrencias de la invasión enemiga han estado suspendidas y se acordó se ejecuten las solemnes de primera clase como antes de practicaban y las demás según se pueda, a cuyo efecto se haga saber a los racioneros, secretario de coro y demás que convenga ${ }^{50}$.

Una de las cuestiones económicas candentes que determinan la situación de decadencia de la Colegiata es un problema pendiente tras la finalización de la contienda civil: el abono de los atrasos a los ministros de dicha institución, cuestión que tensionará las relaciones con los miembros y exmiembros de la mencionada Colegiata partir de 1815.

Asimismo se percibe conforme avanza el siglo XIX una menor frecuencia en las reuniones capitulares del Cabildo desde 1825, síntoma inequívoco del proceso declinante que está experimentando la Colegiata talaverana al disminuir el papel y la influencia de dicha institución en la vida religiosa, artística y económica de la ciudad. Incluso se da el hecho de la ausencia total de actas entre 1840 y 1847.

Por otra parte, llegará un momento en que se discute qué organismos de la Colegiata deben hacer frente al pago de los salarios de los ministros de la Colegiata: así, en 1827 se acuerda por parte del arzobispado toledano que sea sólo la fábrica (tal como se ha venido efectuando desde 1808) la que asuma esta obligación, eximiendo a la mesa capitular ante la escasez de fondos que afectaban a ésta. Por tal razón el arzobispado prohíbe que se contrate a más cantores o ministros del coro:

Oficio del señor Secretario de Cámara de Su Eminencia al señor Obrero de esta Iglesia sobre pago de sueldos por la fábrica a los dependientes del coro, como se practica desde el año de 1808. Y así capitularmente congregados, se leyó el cabildo anterior y un Oficio del señor Secretario de Cámara de Su Eminencia, don Joaquín Fernández Cortina, dirigido al señor Obrero, que a la letra dice así: "Enterado el señor Vicario General de esta ciudad, habilitado para el despacho en ausencia del Cardenal Arzobispo, mi señor,

\footnotetext{
$116 \mathrm{v}$.

49 ACTR, Actas Capitulares, Acta de 21-4-1815, vol. 23, fol.

50 ACTR, Actas Capitulares, Acta de 28-4-1815, vol. 23, fol.
} 
de lo que, con fecha nueve de mayo último, expuso usted a la sagrada persona de Su Eminencia, en consulta sobre si deberían satisfacerse íntegra y exclusivamente de los fondos de la obra y fábrica de esa insigne Iglesia Colegial los sueldos de los ministros de coro, o si para su pago se entendía igualmente sujeta la mesa capitular; después de haber oído sobre el asunto a las personas que ha creído conveniente, y adquirido las noticias oportunas, se ha servido Su Señoría acordar que no se haga novedad por ahora en la práctica que viene observándose desde el año 1808 de pagarse íntegramente por la fábrica de esa Iglesia los sueldos de los dependientes del coro, entendiéndose esto sin perjuicio de acordar a su tiempo lo que convenga en cuanto a la obligación que resulte tener el Cabildo de contribuir por su parte al expresado objeto, y de que ni usted ni el Cabildo, juntos ni por separado, podrán admitir ningún otro cantor o ministro de coro en más número que el que componen los que existen en el día sin nueva determinación con conocimiento de causa aprobada por el eminentísimo Prelado. De orden de dicho señor Vicario lo comunico a usted para su conocimiento y ejecución. Dios guarde a vuestra merced muchos años. Toledo, 5 de octubre de 1827. Joaquín Fernández Cortina" ${ }^{51}$.

La crisis se ahonda en la década de los años 40 del Ochocientos hasta el punto que a comienzos de 1840 la Colegiata se ve imposibilitada de seguir remunerando actos religiosos como misas conventuales y de nona, procesiones, etc. y viéndose obligada a la consiguiente rebaja en la percepción de haberes tanto de canónigos como de racioneros:

También acordó el Cabildo que no hallándose con facultades para seguir pagando las misas conventuales, de nona, procesiones y otros como lamentos, como hasta la presente, hacía rebaja de ellos a los señores canónigos por lo expuesto y a los racioneros por los vestuarios, incluyendo al mismo tiempo a todos los individuos que tienen oficios en esta Iglesia y que el Contador de punto y coro lleve la cuenta desde primero del presente en la inteligencia que el Cabildo ofreció lo referido, siempre que cobre como el año anterior ${ }^{52}$.

La crisis de la Colegiata llega a un momento álgido en 1841 con la supresión de la mesa capitular y de la fábrica debido al deterioro generalizado en la percepción de rentas, lo cual debe enmarcarse en las nuevas reglamentaciones

51 ACTR, Actas Capitulares, Acta de 12-10-1827, vol. 24-3, fol. $113 \mathrm{v}$.

52 ACTR, Actas Capitulares, Acta de 10-1-1840, vol. 24-6, fol. derivadas de las medidas desamortizadoras del gobierno de Baldomero Espartero. Así por ejemplo, se hace constar la situación crítica que están viviendo los miembros de la Colegiata desde 1836 pues "no ha recibido un grano ni maravedí decimal ni del cuatro por ciento. Se ha sostenido con las rentas de sus bienes raíces, constatándose con tal mediocridad que ningún individuo ha percibido ni aún el mínimum que la ley le prescribía" ${ }^{3}$. Hasta tal punto es grave la crisis que ante la inexistencia de la mesa capitular y de la fábrica, se hace necesario enhebrar un plan de supervivencia a partir del primero de enero de 1842 con el fin de que "se guarde el decoro que compete a esta Iglesia Colegial y se conserve el orden que tanto ha distinguido a esta Iglesia", por lo que se adoptan las siguientes medidas:

1. Los canónigos, racioneros y capellanes seguirán cumpliendo con sus obligaciones, las prácticas de coro y altar como hasta ahora se venía ejecutando, percibiendo las asignaciones que el gobierno señale. 2. Los canónigos deberán asumir a su cargo el cumplimiento de las semanas capitulando y celebrando en el altar mayor mientras que los racioneros (incluyendo los organistas) deberán hacer lo propio con los vestuarios. 3. Obligatoriedad de recuperar las semanas cuando se ausentaren por más tiempo del permitido por las huelgas de los estatutos. 4. Sólo se dirán las misas de cuerpo del cabildo, "dejando las cuatro letanías y aquéllas en que asiste el Ayuntamiento" 54 . 5. Se continuará con las invitaciones a maitines pero sin percepción de emolumentos. 6. Reparto de fanegas y cálices de trigo como se he venido efectuando tradicionalmente en la Colegiata y de las deudas que restan por cobrar se abonarán las semanas de canónigos y racioneros. 7. Limitación de procesiones a los domingos, los días festivos, Corpus por la tarde y su Octava, Santa Cena, Mártires de Talavera y Vísperas de la Asunción de Nuestra Señora. Por lo que se refiere a las cuatro letanías y resto de procesiones a las que asiste el Ayuntamiento "se harán por el claustro e Iglesia, excepto la de Corpus y las que pidiera el Ayuntamiento por algún motivo grave o particular, que se harán por las calles de esta villa" ${ }^{55}$.

En cuanto a los empleados de la Colegiata que percibían un salario de la mesa capitular, "cesan desde el primero de enero del año próximo" los maitinantes, la remuneración por capitular las horas, el hisopillo de Completas, el Maestro de ceremonias, el Secretario capitular, el Secretario de punto, el Oficial contador, el Santero por parte de la mesa, el Pertiguero, la Misa de doce y de bienhechores. Se salva del

53 ACTR, Actas Capitulares, Acta de 12-12-1841, vol. 24-17, fol. $\mathrm{s} / \mathrm{n}$.

54 Ibidem.

55 Ibidem. 
cese el receptor de la Mesa, el cual sigue con plenas atribuciones. Respecto a la fábrica y sus dependientes, sus rentas dependerán de lo que el Gobierno de la nación señalare bajo las siguientes condiciones:

1.- Si el gobierno concediese 12.000 reales, 6000 corresponderán a los ministros del coro, Sacristán mayor, Santero, Campanero y Entonador mientras que la otra mitad estaría destinada al servicio del altar, ornamentos, ceras, etc. por todo ello cesaría la misa de ocho y el sobresueldo del Organista ${ }^{56}$.

2.- Finalmente se acuerda que "de lo que diese el gobierno, cuya mitad se asigne como ha dicho, se distribuirá en proporción del salario u dotación que venían disfrutando. Que en caso de que lo que diese el gobierno, cuya mitad se apliquen como va expresado, si la mitad excediese de la dotación o salario, que los ministros del coro y demás dependientes disfruten en tal caso no percibirán esta mitad y sólo si la dotación que ahora tiene" 57 .

Las desgracias para el histórico edificio de la Colegiata continuaron sucediéndose casi sin interrupción a lo largo del siglo XIX. En la noche del 22 de septiembre de 1846 se declaró un devastador incendio que se desató en la nave del norte, atribuyéndose al descuido de un artífice que estaba reparando uno de los órganos. Se destruyeron los dos órganos de la iglesia, la sillería alta y baja del coro, los canceles y ventanas, resultando dañados cuadros y retablos; las llamas invadieron las tres naves del templo, hasta que, a base de un gran esfuerzo, en el que se vieron implicados las autoridades y el pueblo, logró extinguirse el fuego, salvándose gran parte del mueblaje y utensilios, las ropas y las alhajas. Se nombró una Junta local para reparar los daños, y con abundantes donativos en dinero y en especie recogidos en la ciudad, con los de los patronos de las capillas y de otros sujetos forasteros y con el trabajo y prestación personal del pueblo talaverano, se emprendió la restauración del templo, que finalizó en junio de $1847^{58}$.

En esta etapa final, la Colegial contaba con cinco dignidades, diez canónigos, ocho racioneros, seis capellanes y varios ministros. En 1850, y previendo las medidas que se iban a adoptar y ante las noticias que se estaban propagando sobre las reformas eclesiásticas y la drástica reducción de colegiatas que se adoptarían al poco tiempo con la firma del Concordato, el Ayuntamiento talaverano intentó evitar la supresión del cabildo de la Colegiata de Santa María la Mayor en una extensa carta dirigida a la reina Isabel II en calidad de "intérprete fiel de los sentimientos religiosos de

56 Ibidem.

57 Ibidem.

58 LÓPEZ DE AYALA (1959): 309. sus subordinados" 59 , para lo cual arguye que con la supresión del cabildo y de la colegiata desaparecería el brillo y magnificencia con los que se han celebrado las fiestas públicas y además

carecerá de los hombres distinguidos por su carrera e ilustración que siempre ha tenido en su seno el cabildo colegial y que tanto honor y provecho prestan a los pueblos, y finalmente estos moradores hallarán un vacío muy sensible, cuando vean cesar el solemne culto que con tanta gloria de esta Villa se tributa en su templo principal, y que le da mucha importancia en toda la comarca ${ }^{60}$.

La solicitud del ayuntamiento reconoce que el clero se ha reducido a la mitad en comparación con épocas anteriores y de las ocho parroquias antiguas, en 1850 sólo existen cuatro, faltando personal religioso para atender las distintas solemnidades, todo lo cual afecta al culto sagrado, "tan necesario hoy para contener los estragos de la inmoralidad que alcanzará todas partes" ${ }^{61}$. Asimismo, la solicitud hace un repaso histórico de la importancia que ha desempeñado la Colegiata para la vida religiosa y cultural de la población, rogando por ultimo que se haga eco la corona de los perjuicios derivados de la citada supresión del Cabildo de Santa María la Mayor:

A V. M., rendidamente suplica el ayuntamiento que, usando de real clemencia, se digne acoger benignamente esta exposición de los sentimientos de este vecindario, otorgándoles el consuelo de que continúe como hasta aquí esta insigne iglesia colegial, por el lustre y provecho espiritual de esta Villa; o al menos, si tan indispensable fuese la regla general de supresión, que V. M. mandase que se dotare en ella el número competente de capellanes para que, con el párroco de Santa María, como presidente, por hallarse establecida dicha feligresía en el templo colegial, se tributara el culto que fuese compatible con esta innovación, y fuese menos sensible la enunciada supresión ${ }^{62}$.

Efectivamente, el Decreto del 11 de diciembre de 1851 y con motivo de las reformas introducidas por el Concordato, según las cuales se estipulaba qué capillas reales y colegiatas se conservarían $^{63}$, la iglesia Colegial de Talavera

59 Carta remitida por la corporación de Talavera de la Reina en 1850 a la reina Isabel II. AMT, Correspondencia (1850).

60 Ibidem.

61 Ibidem.

62 Ibidem.

63 Para mayor información consúltense ALDEA, MARÍN, VIVES (1972): 593. GARCÍA MARTÍN (2004): 149-150. Sobre las re- 
perdió este carácter, quedando reducida a la condición de parroquia de término, desapareciendo también sus privilegios y prebendas eclesiásticas. García Martín describe cómo afectó el concordato de 1851 al organigrama de la Colegiata de Talavera:

eliminó la figura del "sodeán”, sustituyéndola por la de arcipreste, y añadió la dignidad de "arcediano de Talavera", vinculada a la Iglesia Catedral de Toledo; además, el Concordato redujo a diez el número de canónigos, que se añadían a los ocho racioneros, seis capellanes y ocho presbíteros de que disponía la Colegial. El Ministerio de Gracia y Justicia publicaría la Orden el 25 de junio de 1852, recibiéndola el Vicario eclesiástico de Talavera el 20 de julio ${ }^{64}$.

Efectivamente, a partir del 1 de julio de 1852, el deán de la Colegial se convertía en mero párroco de la nueva parroquia de Santa María. Todos los restantes cargos y sus titulares continuaron pero "en clase de beneficiados, con las obligaciones de asistencia al altar y coro, usando en todo tiempo de sobrepelliz, cooperando además al buen desempeño de la cura de almas y figurando en el presupuesto parroquial con sus actuales dotaciones" 65 .

La defunción de la Colegiata se certificó por el Ayuntamiento en sesión de 22 de julio de $1852^{66}$ y el alcalde se lamentaba añorando "no poder asistir a las horas canónicas y esperando que sea dotada (la iglesia) de suficiente número de capellanes y beneficiados y otros ministros para que siga vivo el culto" "67. Leandro Higueruela narra así las consecuencias de la supresión de la Colegiata en Talavera:

Los canónigos y demás beneficiados, reducidos a simples capellanes, no hicieron sino manifestar su desagrado públicamente, negándose a asistir a coro como protesta, creyendo que el ayuntamiento les iba a pagar estas "asistencias" a los oficios. Sólo fue un gesto testimonial que molestó al alcalde y sirvió para denunciarlo a Toledo por el escándalo que había producido en los fieles ${ }^{68}$.

laciones entre el poder político y la Iglesia en esta etapa histórica, cfr. CÁRCEL (1979): 115-226.

64 GARCÍA MARTÍN (2013): 398.

65 Copia de la Real Orden del Ministerio de Gracia y Justicia, de 25 de junio de 1852, comunicada al arzobispado, y a su vez, al alcalde de Talavera, 20 de junio de 1852. AMT, Correspondencia (julio 1852). 66 ARGANDA (2001): 499.

67 Del alcalde de Talavera a la Reina. Talavera, 24 de mayo de 1852. AMT, Correspondencia (1852). 68 HIGUERUELA (2006): 233.

\section{LA CAPILLA MUSICAL DE TALAVERA EN LA PRIMERA MITAD DEL SIGLO XIX}

Se habla por primera vez de la existencia de una capilla de música en junio de $1656^{69}$ : a partir de entonces se formó un grupo de músicos formada por una serie de cargos a los que se denominaba "músicos", "ministros", "dependientes", etc. que fue ampliándose con el paso del tiempo hasta llegar en el siglo XVIII a su máximo desarrollo. La capilla de música de la Colegiata de Talavera de la Reina estaba formada por una serie de cargos unipersonales con funciones directivas, tales como el Maestro de capilla, el Organista y el Sochantre, así como por una serie de colectivos, entre los que destacan los salmistas, los cantores, los mozos de coro y los instrumentistas.

Sin embargo antes de 1656 es innegable que existía una actividad musical. Aunque en las Constituciones de la Colegiata (1583) no se mencionaba la creación de una capilla, sí que son frecuentes las alusiones a la interpretación vocal de los oficios divinos: así por ejemplo, en el capítulo $1^{\circ}$ se afirma que "las dignidades, canónigos, racioneros, capellanes y clerizones que vinieren a decir los maitines, vengan con hábito clerical y decente, conviene a saber con sotanas o ropas largas o sobrepellices del coro y los canónigos y racioneros a su tiempo con capas de coro, y cuando se dijeren cantados para ganar la distribución de ellos, entren al invitatorio" ${ }^{70}$. Por su parte, el capítulo $6^{\circ}$ establece que

todas las dignidades, canónigos, racioneros, capellanes y clerizones, comenzadas las horas estén en el coro con mucho silencio, devoción y honestidad, cantando y continuando el verso de su coro, haciendo mediación y dejando acabar el otro coro, guardando la solemnidad de la fiesta que se celebrase, lo cual se encarga al Deán o Presidente lo haga bien cumplir, penando al que siendo amonestado, no callare o cantare, procediendo según su contumacia, quitándole una hora de las ganadas cada vez que excediese ${ }^{71}$.

En otro momento de las Constituciones se hace alusión al Sochantre, al que se dedica todo el capítulo $7^{\circ}$ y entre otros aspectos, se afirma que

para el buen gobierno y autoridad de esta Iglesia y que en el servicio del culto divino, no haya falta ni descuido, fol. 165 r.

69 ACTR, Actas Capitulares, Acta de 9-6-1656, vol. 9,

70 Constituciones de la Colegiata de Santa María la Mayor, ACTR, Carpeta 257/40, fol. 2v.

71 Ibidem: fol. $4 \mathrm{v}-5 \mathrm{r}$. 
que el Sochantre resida en el coro a todas las horas y misa conventual para entonar los himnos y antífonas y comenzar los salmos y cuando tuviere alguna ocupación o enfermedad, deje en su lugar persona hábil y suficiente que haga su oficio ${ }^{72}$.

Todo estos datos indican claramente que, con carácter previo a 1583 , debió existir una actividad musical de tipo vocal, relacionada fundamentalmente con la liturgia de los oficios divinos y la misa, tal como se especificaba en las tareas del Sochantre.

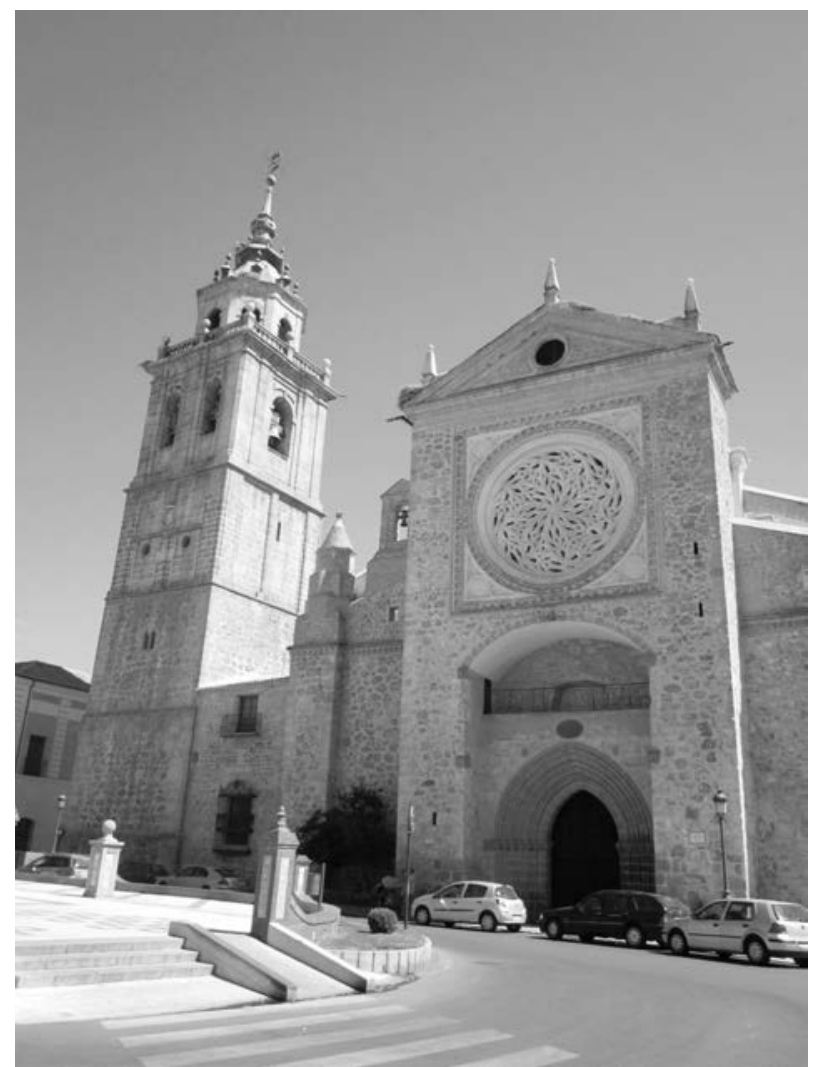

Fig. 3. Fachada de la Colegiata de Santa María la Mayor (Talavera de la Reina)

A pesar de los problemas que pusieron en peligro su viabilidad, la capilla musical de la Colegiata de Talavera de la Reina logró mantenerse a flote hasta su definitiva desaparición en 1851 a causa de la promulgación del Concordato

72 Ibidem: fol. $8 \mathrm{r}$. entre la Santa Sede y el gobierno español. Sin embargo, diferentes problemas pusieron en peligro su subsistencia en diferentes periodos, que se remontan a los mismo inicios de la capilla musical durante el siglo XVII. Sin embargo, la situación más delicada se vivió a finales del siglo XVIII cuando se asiste a un empobrecimiento generalizado de los efectivos de la capilla de Santa María la Mayor a causa de la escasez de buenas voces así como por la actitud de falta de interés por parte de algunos músicos: así por ejemplo, el problema de la carencia de mozos de coro es tratado en julio de 1790 pero lejos de mejorar, se confirma la supresión de cuatro plazas: en vez de 12 , queda reducido el número a ocho ${ }^{73}$. La principal dificultad por la que atravesaba la capilla talaverana estribaba en poder encontrar las voces adecuadas para el servicio litúrgico de la Colegiata. Para remediar tal situación, el Cabildo decidió crear nuevas plazas de cantores y exigió a los componentes de la capilla una mejor preparación y rendimiento artístico pero la situación no se logró enderezar y el Cabildo se planteó por primera vez suprimir la capilla de música en una reunión capitular de diciembre de 1793, pero finalmente se logra llegar al acuerdo de elaborar un plan de reforma de la capilla, que se encarga al canónigo Magistral y Obrero mayor de la Colegiata, José de la Cuba y Avellaneda ${ }^{74}$ : mientras una parte del Cabildo es partidaria de la supresión -entre otras causas por la desobediencia casi permanente de sus miembros y por su participación en fiestas profanas-, otra (liderada por el Deán) opta por el mantenimiento de la capilla si se quiere conservar el boato del culto y porque además sería un motivo de escándalo en la población ${ }^{75}$.

En 1803 el Cabildo es consciente de la necesidad de reformar la música religiosa, con el fin de dotarla de "solemnidad" y "decencia", así como de ampliar los efectivos de la citada capilla. Sin embargo, no deja de llamar la atención que se encargue un completo informe al segundo organista, Juan López ${ }^{76}$, y no al Maestro-Organista titular, Francisco Bernal, lo cual parece indicar que el primero de ellos es el auténtico responsable de la capilla:

73 ACTR, Actas Capitulares, Acta de 16-7-1790, vol. 20, fol. $465 \mathrm{v}-466 \mathrm{r}$.

74 ACTR, Actas Capitulares, Acta de 26-12-1793, vol. 21, fol. $315 \mathrm{v}$. 334-338r.

75 ACTR, Actas Capitulares, Acta de 14-2-1794, vol. 21, fol.

76 La razón de la confianza depositada por el Cabildo en Juan López puede ser debida a que este había desempeñado el magisterioorganistía en Talavera a finales del siglo XVIII, abandonando tal función para poder contraer matrimonio. Dado que se requería las órdenes sacerdotales, cuando quiso retomar sus antiguas labores en la Colegiata (regreso que debió efectuarse entre 1795 y 1800), no pudo reasumir sus anteriores funciones a causa de su estado civil y se tuvo que conformar con la segunda organistía. 
Sobre música. Asimismo acordó el Cabildo se haga saber a Juan López que para que los oficios se celebren con la solemnidad y más posible decencia, se encargue de mandar y componer lo que hayan de cantar y tocar todos los ministros de esta santa Iglesia, así con voces como instrumentos, a los que se notifique estén enteramente a la obediencia y disposición de dicho don Juan y este cuide de recoger la llave de los papeles y todos los que se hallen extraviados en poder de los músicos y señaladamente los que han quedado en poder de la viuda de Vicente Caramaño, quien la encargó su restitución a presencia de José Cabello; y dicho don Juan informe al Cabildo sobre la suficiencia que probaría de Santiago Puebla y lo que sobre su recepción se le ofrezca y le ocurra sobre la materia, procurando se empiece a lograr el fin de este acuerdo en la próxima Pascua ${ }^{77}$.

El informe que Juan López remite al Cabildo da puntual cuenta de las necesidades imperiosas de la capilla en aquel momento, especialmente la contratación de nuevos instrumentistas, como un segundo violín, haciendo hincapié en que la persona elegida domine varios instrumentos, así como de voces diferentes al registro de tenor:

Informe de don Juan López. Y así juntos se leyó el cabildo anterior y en segunda el informe de don Juan López, en que hace presente que Santiago Puebla tiene bastante manejo en el bajón, que posee regularmente las músicas, que en la de facistol necesita bastante ejercicio para poder suplir él solo, que en el canto llano puede suplir muy bien, que sólo se le puede confiar un segundo violín y lo mismo con la trompa, por lo que si se le confiere la plaza que solicita, sea con la precisa obligación de que haya de tocar los tres instrumentos y de que se haya de aplicar especialmente al canto de órgano. A un mismo tiempo hace presente que las voces de que se compone la capilla de esa santa Iglesia son todas tenores, por lo que para poder poner en práctica las órdenes del Cabildo de necesita un contralto y un buen violín, en cuya vista se acordó que dicho don Juan López informe el número y clase de voces e instrumentos que se necesiten los más precisos, explicando los que hay y los que faltan de ellos y entretanto lo arregle con los actuales. Y por ahora se suspende la recepción del bajonista ${ }^{78}$.

En relación con los problemas suscitados con la pervivencia de la capilla musical talaverana desde finales del siglo XVIII, tal como hemos podido comprobar anteriormente, se

77 ACTR, Actas Capitulares, Acta de 16-12-1803, vol. 22, fol. 122r-v.

78 ACTR, Actas Capitulares, Acta de 23-12-1803, vol. 22, fol. perciben síntomas que anuncian la progresiva decadencia de dicha capilla: una situación que se irá agravando conforme nos acerquemos a la supresión de la Colegiata en 1851 y su reconversión en iglesia parroquial, con la consiguiente desaparición de su centenaria capilla musical. Nuevos datos inciden en la progresiva pérdida de importancia de la capilla talaverana conforme avanzaba el siglo XIX: los continuos intentos de abandonar la Colegiata por parte de miembros importantes de dicha capilla, como es el caso del salmista Blas Márquez o las permanentes quejas de los miembros de la capilla, como es el caso de un histórico de la capilla, José Cabello, uno de los protagonistas de su vida musical en la segunda mitad del siglo XVIII y comienzos del XIX, quien se refiere a la "calamidad de los tiempos" en 1805:

Memorial de José Cabello. Últimamente se leyó un memorial de José Cabello, músico de esta santa Iglesia, en que refiriendo el deplorable estado de su persona y familia por la calamidad de los tiempos y enfermedades que han padecido, suplica las gracias de adelantarle doscientos cuarenta reales para pagar la renta de la casa que habita, los que desquitaría en los tres tercios de este año. Y enterado el Cabildo, acordó como lo pide por mitad de mesa y fábrica ${ }^{79}$.

Ante la situación de progresivo deterioro económico, la capilla musical de Talavera se ve en la imposibilidad de captar buenos músicos, tal como ocurría en siglos anteriores. Por otra parte, una de las consecuencias de la Guerra de la Independencia es la deuda contraída con los miembros y exmiembros de la capilla desde 1809 , cuya problemática se suscitará desde 1815, una vez finalizada la contienda. Incluso los familiares de los miembros de la capilla ya fallecidos reclaman muchos años después el devengo de los atrasos, tal como pudimos comprobar anteriormente.

Las dificultades para pagar los salarios abocan al Cabildo a tomar medidas drásticas: ya desde 1808 era la fábrica de la Colegiata la que abonaba los sueldos de sus ministros ante la incapacidad de la mesa capitular, lo cual obliga al Arzobispado a recomendar a las autoridades colegiales de Talavera que "ni usted ni el Cabildo, juntos ni por separado, podrán admitir ningún otro cantor o ministro de coro en más número que el que componen los que existen en el día sin nueva determinación con conocimiento de causa aprobada por el eminentísimo Prelado" ${ }^{\circ 0}$. La ya citada supresión de la

79 ACTR, Actas Capitulares, Acta de 18-1-1805, vol. 22, fol. 204 r.

80 ACTR, Actas Capitulares, Acta de 12-10-1827, vol. 24-3, fol. $123 r$. $113 \mathrm{v}$ 
mesa capitular en 1841 ante su incapacidad para captar nuevos fondos es sintomática de una situación que se convierte en desesperada.

A las dificultades para abonar los salarios se añadieron las solicitudes de contribuir económicamente al sostenimiento de las tropas que resistían al invasor francés ${ }^{81}$. Otra muestra de la creciente paralización que vive la Colegiata es el aplazamiento continuo de decisiones importantes para la vida musical de la Colegiata y la manifiesta incapacidad de adoptar resoluciones: así por ejemplo, en 1840 no se toma ninguna decisión para sustituir al salmista del coro Francisco Manjarín pese a los numerosos pretendientes que desean optar a la citada plaza ${ }^{82}$.

\section{MAESTROS-ORGANISTAS DE LA COLEGIATA DE TALAVERA DE LA REINA EN EL SIGLO XIX}

Se inicia el siglo XIX con el magisterio-organistía de Francisco Bernal entre 1796 y 1808, el cual asumió el control de la capilla talaverana en un momento nada fácil de la historia española pues se trata de la época que antecede la contienda que asola nuestro país. Lo cierto es que con Francisco Bernal al frente del magisterio se inicia el siglo XIX en la Colegiata de Santa María la Mayor.

De procedencia extremeña, nació en fecha indeterminada en la población cacereña de Cañaveral (en la actual comarca de Monfragüe), habiéndose formado musicalmente en la catedral de Coria, donde es citado en una relación de niños de coro perteneciente al año 1780, tal como ha demostrado Pilar Barrios ${ }^{83}$. Su nombramiento como racionero Maestro de capilla-Organista debió tener lugar con posterioridad al fallecimiento del anterior Maestro-Organista, José Cortasa, en 1796. Por la documentación posterior se conocen las nuevas obligaciones que fueron suscritas por Bernal el 9 de marzo de 1798 y que incluyen, entre otras, la obligatoriedad de enseñar gregoriano a los mozos de coro de la Colegiata y de sustituir al Segundo organista en determinados casos o bien la prohibición de intervenir fuera del centro eclesiástico ${ }^{84}$.

La primera noticia documental conservada en relación a Bernal en su ya condición de racionero se remonta a comienzos de 1802 con ocasión de la dotación de misas ${ }^{85}$, si

81 ACTR, Actas Capitulares, Acta de 12-8-1808, vol. 23, fol. $70 \mathrm{r}$.

82 ACTR, Actas Capitulares, Acta de 6-3-1840, vol. 24-16, fol. s/n. 83 BARRIOS (1991): 536. Sobre los antecedentes musicales en dicha Catedral consúltese BARRIOS (1999).

84 ACTR, Actas Capitulares, Acta de 17-1-1834, vol. 24-10, fol. s/n.

85 ACTR, Actas Capitulares, Acta de 15-1-1802, vol. 22, fol. bien al año siguiente dimitió de esta función debido a sus problemas de salud ${ }^{86}$, problemas que vienen reiterándose desde el año anterior, como se desprende de diversos memoriales en los que solicita autorización al Cabildo para ausentarse de Talavera ${ }^{87}$. Las escasas referencias a las actividades propiamente musicales indican con claridad el papel secundario desempeñado por Bernal durante su etapa al frente del magisterio en la Colegiata talaverana: es más, vuelve a rogar que se le libere de nuevas obligaciones ${ }^{88}$. Los problemas con la actuación de Bernal continúan, pues, un año después, el Cabildo se ve obligado a amonestarle por no cumplir debidamente con su función como maestro de los mozos de coro, una de las obligaciones asumidas según el documento antes citado de marzo de 1798, excusándose Bernal en la imposibilidad de enseñar a los mozos que no dominan la lectura ${ }^{89}$. Todo ello, unido a la escasez de noticias relevantes durante su magisterio y al hecho de que no se hayan conservado obras suyas en el archivo talaverano, incide en la impresión de que Bernal no gozó del aprecio y favor del Cabildo de Talavera. Otras referencias documentales a Bernal en Talavera vuelven a relacionarse con cuestiones extramusicales, en este caso con aspectos vinculados al alquiler de una casa: dado que semejante petición había sido efectuada por otro pretendiente, también a Bernal se le niega el arriendo de una casa dependiente del Cabildo ${ }^{90}$, hasta que finalmente al año consiguió su objetivo ${ }^{91}$. A partir de mediados de 1809 tiene lugar un nuevo vacío documental en las actas capitulares y sólo desde 1815 se recupera la normalidad, una vez finalizada la contienda y la ocupación francesa de España.

Gracias a la documentación posterior (acta capitular del 14 de marzo de 1817), motivada por las reclamaciones de Bernal y su deseo de regresar al magisterio talaverano, conocemos que en una fecha indeterminada de la segunda mitad de 1808 Bernal abandonó la Colegiata para refugiarse en su pueblo natal, Cañaveral, hasta que el 7 de febrero de 1814 fue nombrado tanto Organista como Maestro de capilla de la Catedral de Coria con unos emolumentos de 400 ducados anuales y 24 fanegas de trigo: en opinión de Pilar Barrios no parece haber sido excesivamente valorada su actuación en

86 ACTR, Actas Capitulares, Acta de 7-1-1803, vol. 22, fol. 67r. 87 ACTR, Actas Capitulares, Acta de 3-9-1802, vol. 22, fol. 50v. ACTR, Actas Capitulares, Acta de 19-8-1803, vol. 22, fol. 99r. 88 ACTR, Actas Capitulares, Acta de 13-1-1804, vol. 22, fol. $124 \mathrm{r}$.

89 ACTR, Actas Capitulares, Acta de 26-7-1805, vol. 22, fol. $225 \mathrm{v}-226 \mathrm{r}$. $240 \mathrm{v}$.

90 ACTR, Actas Capitulares, Acta de 9-10-1805, vol. 22, fol. $247 \mathrm{v}$.
91 ACTR, Actas Capitulares, Acta de 10-1-1806, vol. 22, fol. $19 r$. 
Coria pues su deseo de ver igualado su salario al del Sochantre (500 ducados anuales) fue desestimada permanentemente e incluso se le censura por los textos de sus villancicos ${ }^{92}$.

Toda la obra musical de Francisco Bernal que ha llegado hasta nosotros se conserva actualmente en el archivo de música de la Catedral de Coria ${ }^{93}$. Por el contrario, en el archivo de la Colegiata de Santa María la Mayor de Talavera no se ha conservado ni una sola obra de este compositor extremeño, lo cual viene a reforzar la impresión de la escasa impronta que dejó tras de sí dicho autor tras su paso por la ciudad castellano-manchega.

Un largo periodo de interinidad se abrió a partir de 1808 y, de hecho, no se volverá a cubrir por oposición la función de maestro-organista, a pesar de los frustrados intentos de recuperar la normalidad y la tradición a la hora de elegir candidatos mediante el sistema que siempre había imperado: la difusión pública de la convocatoria mediante edictos y el correspondiente concurso-oposición "en la forma acostumbrada", como lo demuestra un acuerdo capitular de mayo de $1816^{94}$. Sin embargo, y a diferencia de otras ocasiones, sólo se presentan candidatos escasamente cualificados, como es el caso de Juan García, Sacristán del pueblo toledano de Carmena ${ }^{95}$. El hecho de haber enviado los edictos a la Catedral de Toledo, Catedral de Ávila, Magistral de Alcalá y otro centro indeterminado de Madrid (posiblemente la Iglesia del Buen Suceso), que en el pasado siempre había garantizado la concurrencia de pretendientes solventes, en este caso no aseguraba que la plaza pudiera recaer en "en persona idónea y benemérita", tal como se señalaba en el acta de convocatoria. Una vez transcurrido el plazo legal, el Cabildo pone en conocimiento del Arzobispo Cardenal de Toledo la situación creada ante la falta de candidatos a ocupar la plaza de Organista $^{96}$.

Dos años después la interinidad continúa en la dotación de la organistía talaverana y nuevamente se recurre a la intermediación del Arzobispo Cardenal de Toledo con el fin de volver a emitir edictos llamando a oposición pública: además, la falta de pretendientes también afectaba a otras

92 BARRIOS (1991): 536-538.

93 Se puede consultar on line la catalogación musical de la obra de Bernal conservada en la mencionada catedral de Coria, cuyos responsables fueron los profesores Pilar Barrios y Francisco José Rodilla, y que se encuentra disponible en el enlace siguiente: http://www.nuestramusica.es/coria/catalogo_coria.htm

94 ACTR, Actas Capitulares, Acta de 10-5-1816, vol. 23, fol. $164 v$. $166 r$.

95 ACTR, Actas Capitulares, Acta de 24-5-1816, vol. 23, fol. $169 \mathrm{v}$. funciones de la Colegiata ${ }^{97}$. Más de cuatro años después de que se emitieran edictos (mayo 1816), la plaza de MaestroOrganista seguía vacante, posiblemente debido a "la cortedad de su renta" y todo ello pese al "grave perjuicio que se sigue al culto divino": ante esta grave situación, el Cabildo opta por solicitar autorización al Arzobispo Cardenal de Toledo para nombrar directamente un Organista, aunque sea interino, autorización que es definitivamente concedida por dicho Arzobispo ${ }^{98}$.

La plaza interina de Organista recaerá finalmente en José Leblic, que hasta entonces ha sido miembro del coro. Anteriormente a este nombramiento directo, efectuado contraviniendo la tradición habitual de dotar la plaza por oposición pública, en 1817 se le aumenta el salario para que pueda hacer las veces de Organista y responsabilizarse de la enseñanza de los mozos de coro $^{99}$. Una vez recibida la autorización por parte del Arzobispo Cardenal de Toledo para proveer el nombramiento de Organista de forma directa, José Leblic presenta al Cabildo su candidatura a convertirse en Organista interino; sin embargo no parece tener una opinión muy favorable ya que lo califican de "sujeto sólo algo instruido" y se perciben voces críticas en el Cabildo en contra de su elección ${ }^{100}$. La desconfianza hacia Leblic no había desaparecido del todo pues solicita poder hacer uso del "órgano grande", rechazándose tal pretensión. Todo parece indicar que, a pesar de ejercer la función de Segundo organista, la principal responsabilidad de la organistía seguía recayendo en Juan López: "Memorial del racionero Organista. Se leyó un memorial del racionero Organista solicitando se le permita tocar el órgano grande. Y se acordó que no ha lugar por ahora" ${ }^{101}$. La actuación de Leblic como Maestro-Organista hasta la supresión de la Colegiata y de la propia capilla musical en 1851 pasó sin pena ni gloria: las menciones a su actividad profesional son prácticamente nulas y por otra parte no se ha conservado ni una sola obra musical suya.

\section{CONCLUSIONES}

Si el siglo XVIII representó para Talavera de la Reina una época de florecimiento económico y artístico,

97 ACTR, Actas Capitulares, Acta de 15-5-1818, vol. 23, fol. $230 \mathrm{v}$.

98 ACTR, Actas Capitulares, Acta de 28-7-1820, vol. 23, fol. $284 v$.

99 ACTR, Actas Capitulares, Acta de 10-10-1817, vol. 23, fol. 219v.

100 ACTR, Actas Capitulares, Acta de 2-8-1820, vol. 23, fol. 285 .

101 ACTR, Actas Capitulares, Acta de 11-7-1823, vol. 23, s/n. 
beneficiándose de ello la capilla musical del auge experimentado en la época de la Ilustración española, en el siglo XIX, por el contrario, las rentas de la Colegiata se vieron muy mermadas como consecuencia de las medidas desamortizadoras adoptadas por los distintos gobiernos liberales a lo largo de la primera mitad de aquel siglo, lo cual afectó sobremanera al funcionamiento de la capilla, que disminuyó progresivamente su papel como centro religioso emblemático de la ciudad por la pérdida de solvencia, efectivos y apoyo: ello significó el estancamiento y el definitivo declive que desembocará en la supresión de dicha capilla al reconvertirse la Colegiata en Iglesia parroquial por la aplicación del Concordato de 1851. Una decadencia cuyos primeros síntomas son ya visibles en los últimos años del siglo XVIII, como lo atestiguan los intentos de reforma de la capilla musical con el objetivo de lograr su supervivencia. El análisis de la documentación conservada durante la primera mitad del siglo XIX revela los siguientes resultados:

1. La inacción, manifestada en el aplazamiento de decisiones fundamentales en lo que respecta a la vida administrativa y musical de la Colegiata: así por ejemplo y en relación al ofrecimiento por parte de músicos que aspiran a formar parte de la capilla o el coro, la mayor parte de dichos ofrecimientos no se aceptan o no se toma una decisión definitiva al respecto.

2. El espaciamiento cada vez mayor de las reuniones capitulares, lo que da como consecuencia que los problemas se enquisten.

3. Apenas son tratadas cuestiones musicales en las reuniones capitulares.

4. La reducción progresiva en el número de procesiones desde 1842 constituye un síntoma revelador de las dificultades económicas por las que atraviesa la Colegiata en su última etapa antes de su desaparición definitiva.

5. La incapacidad del Cabildo para captar buenos músicos: así por ejemplo, en 1819 se cita la alarmante falta de salmistas.

6. La ausencia de candidatos a las oposiciones al magisterio de capilla-organistía a partir de 1816, tal como habíamos comentado anteriormente.

Por último, y con el fin completar nuestra visión de la música eclesiástica española, sería necesario tener en cuenta no sólo la actividad de las capillas musicales catedralicias sino también la de las capillas pertenecientes a colegiatas e iglesias parroquiales, que en el caso de Talavera ofrece un extraordinario interés.

\section{BIBLIOGRAFÍA}

Aldea, Quintín, Marín, Tomás y Vives, José (dirs.), Diccionario de Historia Eclesiástica de España, Madrid CSIC, 1972, vol. I.

Álvarez Palenzuela, Vicente Ángel, El cisma de Occidente. Madrid, Ediciones Rialp, 1982.

Arganda, Adolfo, Historia de Talavera cristina II. La Iglesia en Talavera (siglos XVI al XIX). Talavera de la Reina, Tecnigraf, 2001, pág. 499.

Aróstegui, Julio: "El carlismo y la Guerra Civil", José María Jover (ed.), Historia de España. Vol. XXXIV: La era isabelina y el sexenio de democrático (1834-1874), Madrid, Espasa Calpe, 1981: 69-139.

Ballesteros Gallardo, Ángel, Patrimonio artístico de una ciudad: Talavera de la Reina. Ayuntamiento, Talavera de la Reina, 1981.

Ballesteros Gallardo, Ángel, "La colegiata de Talavera: Análisis histórico (siglos XI-XV)", Alcalibe, 2 (Talavera de la Reina, 2003): 277-284.

Ballesteros Gallardo, Ángel (ed.), Santa María la Mayor. VIII Centenario de la Colegial de Talavera de la Reina (1211-2011). Talavera de la Reina, Iglesia Parroquial de Santa María la Mayor, 2013.

Barrios Manzano, Pilar, "La música en la catedral de Coria (Cáceres) durante el magisterio de capilla de Francisco Bernal”, Revista de Musicología, XIV, 1-2 (Madrid, 1991): 535-547.

Barrios Manzano, Pilar, La música en la catedral de Coria, 1590-1755. Salamanca, Universidad de Extremadura y Caja Duero, Salamanca 1999.

Blanco, Miguel Ángel, “Agricultura y ganadería talaveranas del siglo XIX. Ilustración, tradición y fallida reforma liberal", Cuaderna 14-15 (Talavera de la Reina, 20062007): 95-115.

Capdepón, Paulino, La música en la Colegiata de Santa María la Mayor de Talavera de la Reina durante el siglo XVIII. Talavera de la Reina, Ayuntamiento, 2012.

Capdepón, Paulino, "La capilla de música de la Colegiata de Santa María la Mayor en Talavera de la Reina (Toledo)", Hispania Sacra, 131 (Madrid, 2013): 181-237.

Capdepón, Paulino, "El Patrimonio musical de Talavera de la Reina”, Paulino Capdepón y Juan José Pastor (eds.), El patrimonio musical de Castilla-La Mancha: nuevas perspectivas, Madrid, Alpuerto, 2016: 109-173.

Cárcel, Vicente, "El liberalismo en el poder (1833-1868)", Ricardo García Villoslada (dir.), Historia de la Iglesia en España. Vol. V: La Iglesia en la España contemporánea, Madrid, Biblioteca de Autores Cristianos, 1979: 115-226. 
Carrasco, Carmen, "El cólera morbo en Talavera (18341835)", Cuaderna, 9-10 (Talavera de la Reina 20012002): 47-68.

Feijoo Gómez, Albino, La desamortización del siglo XIX en Castilla-La Mancha. Toledo, Junta de Comunidades de Castilla-La Mancha, 1990.

Fernández González, Francisco: "Causas, prevenciones y efectos de la oleada de cólera morbo de 1854-55 en la provincia de Toledo", Anales Toledanos, XVII (1983): 151-175.

Fernández y Sánchez, Ildefonso, Historia de Talavera de la Reina. Talavera de la Reina Imprenta Rubalcaba, 1893 (edición facsímil: Talavera de la Reina, Nupredsa, 1983).

Figuera, Enrique de la, "Las enfermedades más frecuentes a principios del siglo XIX y sus tratamientos", disponible en http://ifc.dpz.es/recursos/publicaciones/ 29/16/11figuera.pdf

Garbayo, Javier, "Liceras Isla, Gaspar de", Emilio Casares (dir.), Diccionario de la Música Esañola e Hispanoamericana, Madrid, Sociedad General de Autores y Editores, SGAE, 2000, vol. 6: 10-11.

Garbayo, Javier, “Soto, Juan”, Emilio Casares (dir.), Diccionario de la Música Esañola e Hispanoamericana, Madrid, Sociedad General de Autores y Editores, SGAE, 2002, vol. 10: 43.

García Martín, Francisco, Gestión del patrimonio histórico $y$ artístico de Talavera de la Reina en el siglo XIX. Talavera de la Reina, Ayuntamiento, 2004.

García Martín, Francisco, "Rentas de la Colegial de Talavera de la Reina", Ángel Ballesteros (ed.), Santa María la Mayor. VIII Centenario de la Colegial de Talavera de la Reina (1211-2011), Talavera de la Reina, Iglesia Parroquial Santa María la Mayor, 2013: 375-400.

García Ruipérez, Mariano, "Hambre y epidemia en Talavera a principios del siglo XIX", en Talavera en el Tiempo. Primer Ciclo de Conferencias 92, Talavera de la Reina, Ayuntamiento, 1994: 212-222.

García Ruipérez, Mariano, "Revueltas sociales, hambre y epidemia en Toledo y su provincia. La crisis de subsistencias de 1802-1805”, Tesis doctoral, Universidad Complutense de Madrid, 2002.

González de Pablo, Ángel, “Asistencia médico-social en Talavera de la Reina, siglos XIII-XIX", Tesis doctoral, Universidad Complutense de Madrid, 2011.

González Muñoz, Maricarmen, La población de Talavera de la Reina. Toledo, Diputación Provincial, 1975.

González Muñoz, Maricarmen, “Años de destrucción. Pérdidas en el patrimonio histórico de Talavera de la Reina en la década de los setenta (s. XX)", Cuaderna, 18-19

(Talavera de la Reina, 2010-2011): 161-178.

Gonzálvez, Ramón, "Estudio histórico y diplomático del Documento Fundacional de la Colegiata de Talavera de la Reina”, Ángel Ballesteros (ed.), Santa María la Mayor. VIII Centenario de la Colegial de Talavera de la Reina (1211-2011), Talavera de la Reina, Iglesia Parroquial Santa María la Mayor, 2013: 33-81.

Hernández Lanchas, Manuel, La crisis del Antiguo Régimen en el santo Hospital de la Misericordia de Talavera de la Reina (1789-1837). Toledo, Instituto Provincial de Investigaciones y Estudios Toledanos, 1991.

Higueruela, Leandro, "La mancomunidad de pastos de Talavera y su tierra. Un pleito entre ganaderos y agricultores (1836-1840)", Anales Toledanos, XV (Toledo, 1982): 109-137.

Higueruela, Leandro, La diócesis de Toledo durante la Guerra de la Independencia Española. Toledo, Editorial Zocodover, 1983.

Higueruela, Leandro, Talavera durante la década moderada (1844-1854). Talavera de la Reina, Ayuntamiento, 2006.

Leza, José Máximo (2014) (ed.), Historia de la música española e hispanoamericana. 4 La música en el siglo XVIII, Madrid, Fondo de Cultura Económica, 2014.

López de Ayala, Jerónimo: Catálogo Monumental de la Provincia de Toledo. Toledo, Diputación Provincial, 1959.

López de Ayala, Pedro, Crónicas de Pedro I, Enrique II, Juan I y Enrique III. Madrid, BAE, 1979.

$-802$.

Madoz, Pascual: “Talavera de la Reina”, en Diccionario geográfico-estadístico-histórico de España y sus posesiones de Ultramar, vol. XIV, Madrid, 1849: 565-575.

Mendoza Eguarás, Mercedes, Torroja Menéndez, Carmen, Catálogo analítico del Archivo de la Colegiata de Talavera de la Reina, 1204-1900. Toledo, Diputación Provincial, 1969.

Messa Poullet, Carlos, “López, Juan”, Emilio Casares (dir.): Diccionario de la Música Esañola e Hispanoamerica$n a$, Madrid, Sociedad General de Autores y Editores, 2000, vol. 6: 999.

Miñano, Sesbastián de, "Talavera de la Reina”, en Diccionario Geográfico-Estadístico de España y Portugal, vol. VIII, Imprenta de Pierart-Peralta, Madrid 1827.

Monterrubio Pérez, Ángel: La instrucción pública en Talavera de la Reina en el siglo XIX. Talavera de la Reina, Ayuntamiento, 1999.

Nicolau Castro, Juan, "La Colegiata de Talavera de la Reina", Anales Toledanos, IV (Toledo, 1971): 83-200. 
Nicolau Castro, Juan, "Datos documentales sobre la Colegiata de Talavera de la Reina", Anales Toledanos, XV (Toledo, 1982): 19-39.

Olmedo Ramos, Jaime: "Ocho siglos de cultura y devoción: la Colegiata de Talavera (1211-2011)", en Ángel Ballesteros (ed.): Santa María la Mayor. VIII Centenario de la Colegial de Talavera de la Reina (1211-2011), Iglesia Parroquial Santa María la Mayor, Talavera de la Reina 2013., págs. 13-32.

Pacheco, César: "La revolución de 1868 en Talavera de la Reina", en Talavera en el Tiempo. Primer Ciclo de Conferencias 92, Talavera de la Reina, Ayuntamiento, 1994: 225-239.

Pacheco, César, Valverde, Inés, "La transformación del espacio urbano de Talavera en el siglo XVI", Cuaderna, 1 (1994): 32-56.

Peñalver, Luis Francisco, "Talavera de la Reina, mayo de 1814: ¡Que se queme la Constitución! Acontecimientos en Talavera tras la llegada de Fernando VII a España. La vuelta al absolutismo", Cuaderna, 14-15 (Talavera de la Reina, 2006-2007): 79-94.

Pérez Grande, Margarita: La platería en la Colegiata de Talavera. Toledo, Instituto Provincial de Investigaciones y Estudios Toledanos, 1985.

Pinilla Navarro, Vicente José: "Sobre la agricultura y el crecimiento económico en España (1800-1935)", Historia Agraria, 34 (Murcia, 2004): 137-162.
Portela Hernando, Domingo, "Origen y evolución del cristianismo en Talavera", en Ángel Ballesteros (ed.), Santa María la Mayor. VIII Centenario de la Colegial de Talavera de la Reina (1211-2011), Talavera de la Reina, Iglesia Parroquial Santa María la Mayor, 2013: 111-256.

Prieto Araújo, María, " 2 de octubre de 1833: un talaverano en pie de guerra", Alcalibe, 9 (Talavera de la Reina, 2009): 241-283.

Rubio, Félix, El pronunciamiento carlista de Talavera de la Reina, Toledo, Instituto Provincial de Investigaciones y Estudios Toledanos, 1987.

Rubio, Félix, "El primer levantamiento de la guerra carlista en Talavera de la Reina (Toledo), 2 de octubre, 1833", I Congreso de Historia de Castilla-La Mancha. Vol. 9: Transformaciones burguesas, cambios políticos y evolución social, Toledo, Junta de Comunidades de Castilla-La Mancha, 1988: 63-67.

Sánchez Garnica, Paloma, "La beneficencia en Talavera de la Reina durante la ocupación francesa (1808-1814)”, Cuaderna, 11 (Talavera de la Reina, 2003): 60-72.

Suárez Fernández, Luis, Estudios sobre el régimen monárquico de Enrique III de Castilla, Madrid, CSIC, 1953.

Yoshiuki Kondo, A.: La agricultura española en el siglo XIX. Madrid, Nerea, 1990.

Recibido: 18.05 .2017

Aceptado: 03.09.2017 